\title{
2017 年春季学術大会シンポジウム
}

\section{熊本地震からわれわれは何を学ぶべきか一地理学からの発信一}

\section{趣旨と概要}

鈴木康弘（名古屋大学）

宇根 寛（国土地理院）

久保純子 (早稲田大学)

2016 年熊本地震は, 阪神淡路大震災以来 21 年ぶりに 起きた比較的大規模な内陸直下地震であり, 地震本部 が主要活断層として長期評価を公表してきた布田川昏奈久断層が起こしたものとして，注目を集めた。長 期評価が正しくなされていたか，またその情報が住民 にどの程度伝わり，被害軽減に役立ったかどうかの検 証も求められる。地震本部は4月 14 日のM6.5の地震 は日奈久断層で起き，4月16日のM7.3の地震は布田 川断層が起こしたと発表しているが，前者の震源域は 後者の震源域に完全に包含されるため, 一連の断層が 起こした前震と本震であると理解した方が良いとする 見解もある（鈴木ほか2016）。

この地震による人的被害は，2017年3月 14 日消防 庁発表によれば, 直接死 50 人，間接死 158 人（うち 5 人は豪雨との複合災害）であり，間接死の割合が高 い. また，益城町では前震と本震の二度にわたって震 度 7 になり被害が拡大したほか, 4,200回を超える余 震が繰り返したため避難が長期化した。 また，全壊建 物棟数当たり避難者数が阪神・淡路大震災の 10 倍に のぼった。こうした点に中央防災会議は特に注目して 検討を進めた。

その他の主な課題としては, 震度7相当の強い摇れ が活断層沿いに局地的に起こり，復旧復興において活 断層沿いの土地利用が議論され始めた。また，熊本県 内の工業集積地が被災したことから地域経済への深刻 な影響が現れた。また，被災地における心のケアや， 今後の防災・減災教育のあり方も大きな問題となっ た. 地理学界としては, 今後の高等学校「地理総合」 への反映も課題となっている.

こうした状況の中で,「地理学として何を学び, 何 を発信して行くべきか？」を検討することが本シンポ ジウムの趣旨である. 周辺学問分野との連携や地理学
のどのような研究教育を強化すべきか？も考える必要 があろう。 以上の趣旨から, (1)熊本地震と活断層, (2)被害の地理的要因, (3)産業立地と復興計画, (4)復興 と防災教育，の四つに焦点を当て，地震の現象解明と 対策論における地理学の貢献のあり方を議論した.

シンポジウムでは, 活断層研究, 液状化およびハ ザードマップ研究, 地域経済・地域計画研究の立場か ら報告とコメントがあり, また, 被災地大学としての 支援のあり方や防災・減災教育について報告され，各 講演に関するコメントがなされた。

以上の発表から, 地理学会会員が熊本地震の現象解 明から被害の要因分析，復旧復興計画づくり，防災教 育に至るまで広範囲で，最先端の調査研究を行ってい る状況が明らかになった。 そこで得られた多くの知見 は，災害に関わる関連諸学会の成果の中でも重要な位 置を占めている。 また，被災地の地理学者の活躍が際 立った。

総合討論においては，被災者へ気遣いながら研究を 進める際の留意点が地元地理学者から披露され, 地理 学会全体で共有することの重要性を確認した。また， 今後目指すべき課題として, (1)活断層研究から事前の 地震（特に摇れ方）の予測精度を上げる，(2)地形発達 や土木史から液状化ハザードマップを向上させる, (3) 熊本地震は何だったかを地誌学的に把握し, (4)地域経 済の自立化・多極分散化を伴う復興を提案する，(5)被 災地の大学の役目を考える, (6)活断層との共生をまち づくりと防災教育の面から考える，(7)地域性を反映し た防災教育のあり方を探る，等があげられた。

災害事例を分析し，社会構造と災害発生の関係を理 解することは重要である。しかし単なる理解に留まら ず，今後は防災対策の制度論や国土・地域計画への反 映について積極的に発信することが求められる. 


\section{研究発表およびコメント} 熊本地震の地震断層調査に基づく今後取り組むべき課 題

\section{熊原康博（広島大学）}

2016年 4 月に発生した熊本地震に伴い, 長さ $30 \mathrm{~km}$ を超える地表地震断層が発生した。熊本地震を受け て, 変動地形学の研究者が今後取り組むべき課題を提 示した.

1）今回の活動の普遍性の検証

今回出現した地表地震断層の変位量や範囲につい て，過去の活動も同様であり，なぜそれが繰り返して きたのであろうか？この疑問に対して，過去の活動 の累積である断層地形や断層近傍の地層の情報に基づ いて今後検証を進めていく必要がある，特に，今回は 地表に生じた地震断層がすべて陸上に現れていること から，この問題を検証する上で適切な事例となりうる といえる.

2）地形判読に基づく活断層線と地表地震断層の位置 の齟䶜の解明

熊本地震では, 変動地形学的なセンスからは想定で きない位置に地表地震断層が出現した．想定外の現象 が地下の地質構造に規定されたものなのか, あるいは もともとは推定した活断層トレースを通過していたも のが現在のトレースに変化したのか, などを今後検証 する必要がある。

3）正断層の変動地形に対する認識

正断層性の地表地震断層が, 断層崖基部だけでな く，断層崖の中腹でも多数認められた．日本列島のほ とんどの活断層が，水平圧縮に伴う逆断層や横ずれ断 層であり，一般的には，これらの断層では断層崖の基 部に地震断層が生じることが多い。正断層の調査の際 にはこの点にも留意することが必要と考える.

4）デジタル標高モデル（DEM）の活用

地表地震断層は植生に覆われた山地内を通過するこ とも多く，森林下の微地形をとらえたDEMを用いた 地形判読が有効であった。今後DEMを利用した活断 層調査を積極的に進め，より正確な断層トレースを認 定することが望まれる。

5）干渉合成開口レーダーの解析との比較検証

干渉SARの解析により，これまで検出できなかっ た微少な地表変位も認められ, 現地調査に基づく地表
変形の位置や変位の向きとも調和的であることが示さ れた。 今後の調查でも, 干渉SARの解析と現地調査 の比較検討が重要になるといえる。ただし干渉SAR に基づいた変位は，数 $\mathrm{cm}$ オーダーで変動がわかる一 方，変位量が大きい部分は計測することはできないこ とから, 現地調査に基づく地表地震断層の調查の有用 性も残る.

九州地方中部には，正断層性の活断層が数多く認め られているが，この断層の中には，横ずれ変位が見逃 されているかもしれない. 断層崖の基部だけでなく, 断層崖の中腹に変位地形が存在する可能性があること を留意しつつ, 詳細な DEMデータの活用することで, これまでとは異なる成果が得られる可能性がある.

\section{コメント 1}

中田 高（広島大学）

2016年熊本地震は, 布田川-日奈久断層の主として 北半部の活断層の再活動によって引き起こされたもの であるが, 活断層の存在が指摘されていなかった場所 でも地震断層が出現した（熊原ほか2016; Shirahama et al. 2016)。このような地震断層の特徵を総括した熊 原康博会員は，断層の活動の普遍性の検証など，今後 取り組むべき課題を提示した。

これ以外の重要な課題として, 地震断層と建物被害 の関連の解明が挙げられる，熊本地震では，巨視的に みると, 被害は震源域から遠ざかるほど地震の摇れは 小さくなり，家屋被害が小さくなるという傾向が認め られるが，微視的にみると甚大な建物被害が地震断層 直上と地震断層の近傍の限られた範囲で発生した（藤 原 2017 など)。前者は断層のずれによる建物破壊であ り，後者は強い地震動によるものである，後者は，地 震断層に沿って普遍的に認められる訳ではなく，益城 町木山地区, 南阿蘇村黒川地区などの横ずれ変位が卓 越する地震断層の末端部などに偏在する特徵が認めら れた．布田川断層とそれから分岐する地震断層は，益 城町堂園付近から南と北に向かって分岐する平面形状 を示しており，中田ほか（1998）の破壊伝播予測モデ ルに対応して，これらの被害集中地域ではディレク ティビティ効果による地震動の増幅が起こったと考え られる。また，益城町平田周辺などの地震断層がス テップするなど破壊の伝播が阻害されるような場所で 
は建物被害が目立ち，地震動が局地的に大きくなった 可能性がある.

これに対して, 布田川断層に沿った地震断層の横ず れ変位が卓越する断層の直線的なトレースでは，ごく 近傍でも建物が倒壊した例はほとんどなかった。これ は，断層破壊がスムーズに伝播したことを暗示してい る.ささら，布田川断層の南に平行する出ノ口断層な どの正断層変位が卓越した地震断層に沿っては, 断層 直上を除けば建物の倒壊は認められず，これらの断層 に沿っては破壊的な地震動は発生しなかったといえる.

甚大な建物被害は，地震断層に沿った幅狭い範囲に 集中したことから, 破壊的な強振動が地震断層 = 活断 層に沿って地下の極浅部から発生したと考えることが できる，熊本地震を事例に，地震断層と建物被害の分 布の関連をさらに詳細に検討し, 活断層の変位様式と 分布形状をもとに破壊的な摇れが発生する場所を地震 発生前に予測する手法を開発することが，地震災害軽 減に資する変動地形学の新たな重要な課題の一つとし て挙げられる.

地理学の立場からみた 2016年熊本地震における液状 化被害分布と土地条件

\section{小山拓志（大分大学）} 青山雅史（群馬大学）

2016年熊本地震によって, 熊本平野の広域かつ多 数の地点において地盤の液状化が発生した。本研究で は, 現地踏査や衛星画像等の判読による液状化発生地 点のマッピング, GIS と地理空間情報を用いた解析, 絵図や文書資料の分析などから，液状化発生地点の土 地条件 (地形条件) および歴史的土地利用（履歴）を 検討した。

液状化発生地点は, 自然堤防, 旧河道, 盛土地にお いて相対的に多く分布し，氾濫平野と海岸平野·三角 州においては相対的に少ない傾向がみられた。また， 沿岸部の干拓地においては，白川河口部右岸では液状 化発生地点が多数分布するが, 干拓地内のその他の領 域での液状化発生は少なかった。緑川流域では，砂利 採取場跡地における液状化の発生が認められた。本地 震による液状化発生地点の分布は, 熊本市が公表して いた液状化ハザードマップの被害想定とは異なる傾向 がみられた。
白川下流域左岸の複数の自然堤防においては, 多数 の液状化発生地点が帯状に分布する領域がみられた. 特に，熊本市南区近見付近から元三町付近まで延びる 自然堤防上においては, 幅 $100 \mathrm{~m}$ 未満の限定された带 状の領域で液状化被害が集中的に発生し, 多数の構造 物被害が生じた（液状化の帯）。この被害分布の形態 から，液状化が発生した領域には，この自然堤防を形 成・発達させた河川がかつて存在していたと考えられ

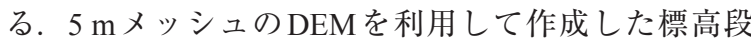
彩図では，この液状化発生域の一部に帯状の谷地形が 認められることからも，この地域に河川が存在してい た可能性は高い. しかし, この地域の最も古い旧版地 形図（1/20,000：1901年測図), さらに江戸期の伊能 図や絵図をみる限りでは，近見付近において水域の埋 め立てや旧河道の存在は見出せず，白川河道は江戸初 期にはすでに現在とほぼ同じ位置にあったと推測され る.一方で，同地域には 13 世紀後半に川尻地区（元 三町付近）で白川と緑川が合流していたことを記述し た文書 (大慈寺文書) が存在している.このことか ら，白川が川尻方面に南流していたのは，江戸期初期 以前までであった可能性がある.

以上を踏まえ, 南区近見付近から南区元三町付近で は，既存の地形分類図では表現されていない旧河道に おいて液状化が発生した可能性が高い。今後は, 河道 変遷に関する地形・地質学的調査や, 水路の造成・埋 戻しなどの土木史に関する検討が必要である.

\section{コメント 2}

黒木貴一（福岡教育大学）

小山・青山報告は, 熊本地震による液状化発生地点 の微地形を現地・資料確認し, 既存研究成果や微地形 区分に基づく液状化判定基準との共通・相違点の双方 を見出した。 また液状化ハザードマップの表示と実際 の発生地点とが甚だしく異なることも示した.

前者の共通点に対し, 空中写真の時系列的な観察を 通じて要因を示した。一方，前者の相違点，特に自然 堤防での集中発生に対しては, SAR干渉画像, 詳細 DEM, 古地図や笠書を検討に加え, 空中写真の限界 を越えて，液状化しやすい表層の地質情報を補ってい る。近年 DEM等による情報解析を通じた定量的な問 題解決型研究が増したが, この取組み過程では, 地形 
学が最新技術から得た情報も定性的・主観的情報も同 等に検討材料としており, 経験則の積み上げを問題解 決に用いる地理学独特の手法を再認識させられた.

後者はボーリングデータによる液状化可能性の評価 時に, 表層の地質情報の分解能が液状化に関わる微地 形を意味するほど精緻ではなかったことを示してい る. そこには地形学と地盤関連他分野との相互理解に 至る情報交換が密ではない現状が背景にあろう。とは いえ，今ある治水地形分類図や土地条件図に示された 地形区分でも, 液状化発生地点の説明は十分にはなさ れない。これは両図が洪水汇濫の被害軽減の思想で設 計されており，液状化予測には時空間的な解釈が必要 だからである。

微地形に基づき液状化が評価された今後のアウト プットでは，解釈を支援する新たな地理情報の付加が 求められよう。たとえば表層地質と水賦存を推定する ため，旧版地形図の重ね合わせで地形変化範囲や変化 量の情報取得が考えられる。また発表者は，液状化発 生場に関し, 大局的には熊本平野の広域の視点, 狭い 範囲では局所的な視点双方をもち，研究を進めた。こ のマルチスケールの視点もアウトプットの設計思想に 取り入れるべきで, 微地形にとらわれず，土砂の堆積 場となる地下構造を広域で解釈できる情報の付加も必 要ではないだろうか．たとえば都市圈活断層図であ る.

このように考えれば，発表者の意図は，今回の液状 化災害の実態紹介にとどまらず，地震災害予測に直結 する表層の地質情報の解釈がしやすい地理情報のアウ トプットは今後どうあるべきか，という地理学への問 題提起を図ることにもあったように思えてならない.

\section{熊本地震と製造業一地域経済の復興に向けて一}

鹿嶋 洋 (熊本大学)

2016年熊本地震は, 特に熊本都市圈東部地域に大 きな被害をもたらした。この地域は熊本県内で最も製 造業が集積した，いわば「稼げる地域」である。その ため，製造業への被害は地域経済全体に幅広い影響を 与えた，本報告では，熊本県の基幹産業の一つである 製造業を取り上げ，熊本地震の被害と復旧状況を概観 するとともに，地域経済の復興に向けた課題を整理す ることを目的とした
当地域は長年にわたる誘致政策によって, 半導体, 輸送用機械などの誘致大企業が次々に進出し, それら のサプライヤーである地元中小企業や進出企業が集積 し,「誘致型複合集積」（中小企業庁 2006）と性格づ けられる。震災の影響を考察する上でも，このような 地域特性を踏まえる必要がある。

誘致大企業については, 建物, 設備の損傷などの直 接的被害による操業停止が多発した。多くの工場は 1 週間から 1 力月程度で比較的早い復旧を遂げた。東日 本大震災を機に各社が策定・改訂を行った事業継続計 画（BCP）が奏功したともいえる. しかし，物的被害 の甚大な企業の中には生産停止が長期化したものや, 生産再開を断念した例もある。他地域（海外含む）で の代替生産に切り替えた企業もみられた。

間接的な影響としては, サプライチェーンの寸断に よって, 他地域の工場に生産停止が波及する例があっ た．早期の生産再開のために県内協力工場での応援生 産が行われたが，それに際してはグループを挙げた協 力体制が寄与した。

地元企業についても直接的被害の度合いによって影 響は大きく異なるが，加えて経営者や従業者の高齢 化，設備の老朽化の度合いなども復旧を左右するよう である．大企業に重要部品を供給する地元企業に対し ては，大企業が復旧を全面的に支援する傾向にある。 これまで縁のなかった他地域の同業者から設備を融通 されて早期の復旧を果たすなど，他地域からの支援も 重要であった，他方，他社で代替可能な製品を扱う地 元企業にあっては，生産停止中に取引を失う場合もあ る。また生産停止が長期化した地元企業は従業員の解 雇を余儀なくされ，再開後の労働者の不足にも直面し ている.

今後，さらに実態調査を進めることにより，製造業 の被災状況の地域差とその要因を実証する必要があ る。その際には，地域内外の諸要素との関連を総合的 かつ長期的に視点が不可欠と考えられる.

\section{コメント 3}

戸所 隆（高崎経済大学）

鹿嶋氏は, 震災が(1)誘致企業依存の産業構造と熊本 都市圈一極集中的県土構造の脆弱性と, (2)地域経済の 自立化と多極分散型德興の必要性を明らかにした．災 
害復興や防災・減災計画策定には災害地域の実態を把 握し, 災害に強い地域像の実現が求められる。 その 際, 鹿嶋報告のような地理学研究は有用であり, 社会 に向けての情報発信が重要となる.

自然災害の発生は(1)地域社会の弱点を容赦なく突 き，(2)地域経済を支える基幹産業衰退の契機になりや すい。これを防ぐためには，災害前から日常的に災害 復旧に備える事前復興が求められ，(1)復興方針に関す る住民意識の統一，(2)地域の弱点発見とその解消が重 要となる。また，事業所では事業継続計画BCPが久 かせない.

事前復興で地域の弱点強化や事業所活動を支えるに は，日常的に鉄道網・道路網・通信網等の国土基盤強 鞀化が不可欠となる。たとえば，国土構造のフェイル セーフ, リダンダンシー機能強化には国土縦断軸を補 完する横断軸の整備が求められる。 また，小規模自治 体や単独経営の中小企業は被災により孤立化しやす い. 同時被災しない広域における関係組織間のネット ワークを構築し，交流による災害対応力向上が重要と なる.この場合，とかく支援力に片寄りがちになる が，支援力と共に受援力強化が必要である.

地域に十分根差していない被災誘致企業の撤退で, 地域経済が衰退するケースが多い. しかし, 誘致企業 でも基盤技術を支える人材の育成と集積で，撤退でき ない環境の構築が可能となる，独自技術をもつ人間が 集積し，技術の維持発展力を構築した地域は，災害後 も自力更生型復興・地域形成・事業再生を実現しやす い.そのためには独自技術を創造・支援する教育シス テムと事前復興を支える教育環境への再構築が求めら れる。

東京一極集中の是正や均衡ある国土構造 ·人間力向 上は，災害国日本において甚大な自然棪害からしなや かに立ち直るために不可欠な方向性である。この視点 から災害現場で綿密な調查研究を実施する地理学研究 は, レジリエントな国土構造への再構築への貴重な発 進力となるといえる.

\section{熊本地震からの復興とボランティア支援一被災地の地 元大学としての支援のあり方一}

高木 亨 (熊本学園大学)

被災地にある大学として何をしなければならないの
か？ 今回，われわれに突きつけられた課題であっ た．報告者はこれまでの復興支援経験を活かしつつ， また前職のネットワークを活用し，福島から支援を受 け，模索しながら活動してきた。

その一つが, 熊本学園大学学生が中心となって運営 する「おひさまカフェ」である。「おひさまカフェ」 は被災地域でのコミュニティ再構築を目的としたサロ ン活動として, 益城町保健福祉センター避難所で始 め, その後テクノ仮設住宅団地で活動を継続してい る。2016年 5 月末からほぼ毎週土日に開設，カフェを 中心としたコミュニティができあがった．これは，継 続的に支援活動を続けてきた一つの成果といえる.

ところで，地域活性化には「よそもの」「わかもの」 「ばかもの」の「三もの」が必要だといわれている. 報告者がこの活動を通じて感じたことは，災害からの 復興期にも「三もの」が必要ということである，学生 が地域活性化に果たす役割と同様に，被災地の復興に も重要な役割を担える。これは平時の取組みの応用 で，復興期の支援活動が可能なことを示している。 ま たこれによりよそものである学生が，将来的には記 憶の継承の役割を担う「当事者」になる可能性が生ま れている。

最後に，被災地にある大学からの情報発信の必要性 とアカデミックの使命について考えたい。被災地にい る地理学者としては, 時間軸と空間軸に応じた情報発 信が求められる。これらがあやふやな情報がもたらす 「風評被害」を防ぐための情報整理が必要である。ま た，被災地域の特徴や社会・文化的背景を踏まえた情 報発信は重要である.

アカデミックの使命としては, goodから badまでの practiceを集め，次につなげる役割がある。これらを 通じて，Build Back Better（BBB：より良い復興）の ための情報発信を続けていくことが重要である.

そうした中，復興を急ぎたい「権力」側と「災害 （社会的）弱者」とのコンフリクトが生じる，その場 合，アカデミックとして強調される「科学的客観性」 だけで，BBBが可能なのであろうか.「権力」の意味 を鑑み，研究者の立ち位置として，「弱者のBBBのた めという視点」が必要ではないか. 災害 disasterは地 理学がフィールドとする地域をさまざまなかたちで 「破壊」する。その地域の復興には，これまで培われ 
たノウハウを活かした，地理学者としての災害への対 応が求められている。

\section{コメント 4}

\section{宇根 寛（国土地理院）}

2016年熊本地震による二度の震度7に襲われ，市街 地中心部に壊滅的な被害を受けた益城町では, 震災か らの迅速な復興を進めるため, 2016年 7 月から復興計 画の検討に着手し，同年12月に益城町復興計画を策 定した。計画では，「住み続けたいまち，次世代に継 承したいまち」を揭げ，五つのシンボルプロジェクト と八つの分野別取組みを示している．全体の都市構造 としては，大きな被害を受けた市街地中心部を再び都 市拠点として再興することとされている．計画策定に あたって全住民に行われたアンケートでは，8\%の住 民が，町外に移転したい，またはすでに移転して戻る つもりはない, と回答しており，その理由として，多 くの住民が，地盤が心配，また再び地震が起きること や断層が心配，といったことを挙げている．このた め, 国土交通省都市局は, 都市拠点として再整備する 市街地中心部の地盤状況, 活断層位置を把握して町の 復興に資することが必要との観点から，ボーリング調 査, 物理探査, ピット調査等を内容とする「熊本地震 からの益城町の市街地復興に向けた安全対策のあり方 等に関する調査」を実施し，2017年3月に報告書を公 表した。これによると, 市街地に 3 本の活断層が存在 し, 今回の地震ではそのうち最も南のものが最大 $35 \mathrm{~cm}$ の右横ずれ，および $15 \mathrm{~cm}$ の上下変位を地表に もたらしたことが確認され，また将来も今回と同程度 の活動を起こすことが推定されるという．同報告書で は，杭基礎構造を有する中高層建築物等を建築する場 合は，活断層による地盤のずれによる被害リスクも想 定されるため，地盤調査等により活断層の存在の確認 等を行うことを提案している，また，土地区画整理事 業等により面的な市街地整備を行う際には，事業の計 画を，被害リスクの回避の観点から活断層上の土地利 用に配慮したものとすることが有効と考えられるとし ている，益城町復興計画においては，シンボルプロ ジェクトの一つとして「日本の防災・減災をけん引す る復興プロジェクト」が掲げられており，また，分野 別取組みには「活断層との共存」「震災記録の後世へ
の伝承」「防災教育の充実」「震災メモリアル回廊の整 備」などの項目が並び, 活断層や震災から目を背けず に復興を進めようとする姿勢がみられる。地理学に は，その成果を活かし，被災地の復興，災害に強い町 の再建に貢献することが期待されている.

\section{熊本地震後の防災・減災教育}

竹内裕希子（熊本大学）

熊本県南阿蘇村立南阿蘇中学校における熊本地震後 の防災教育の取組み事例から, 中学生の共助力向上の 検証を目的とした。

一般的に防災教育で取り上げられる内容は，まち歩 きなどによる地域の安全確認や地図作成, 緊急時の避 難行動が挙げられる。これらは平常時に自助力を高め るための防災教育として重要であるが，中学生という 立場は，これまで家族や地域の中で守られた存在とし て生活してきた小学生と異なり, 地域の一員として地 域を守る存在になれることから，共助に関する防災教 育に取り組むことは地域防災向上につながると考えら れる．特に高齢化が進む地域では，中学生のような平 日昼間に地域に滞在する若年層が共助力向上に寄与す ることが期待される.

南阿蘇中学校における防災教育は，共助の一つであ る避難所運営に重点を置き，全校生徒（261名）を対 象に実施した．実施のタイミングは，生徒の心的スト レスに配慮し，村内の避難所が全て解消し，発災後半 年を過ぎた頃を目処とした。自然災害の仕組みと防 災・減災対策に関する概要を講義で行った後，静岡県 が作成したカードゲーム HUG を実施し，その後熊本 地震の経験を活かした南阿蘇中版 HUGの作成，作成 したHUGを3次元で実施する「リアル HUG」などの 演習を中心に20コマ（1コマ50分）で構成した。

授業の前後アンケートから，「地域にはさまざまな人 がいること」「支援を断ることも必要であること」「中 学生も地域のためにできることがあること」への認識 については，肯定に大きな変化があったことが確認さ れた。一方で，「これからも南阿蘇村に住みたいと思 う」という質問は肯定が減少する傾向がみられた。こ れは，自然災害という視点のみで地域の自然的要素 · 社会的要素を学んだ場合, 地域の脆弱さが強調される ことになったことが要因であると考えられる。多くの 
恵み・利点を含めたさまざまな側面を地域学習として 学んでいく中の一部に, 防災教育を位置づけていく必 要がある.

今回の防災教育を通じて, 生徒は避難所運営の仕組 みを学び，共助における自身の役割について考える機 会となっただけでなく, 熊本地震の経験に基づき地域 性を反映した教材の作成をしたことが成果として挙げ られる。また，作成したカードを実際に生徒が演じる ことにより, 静岡県作成の避難所運営ゲーム HUGの 課題とされる3 次元で実施した際の莓齠についても解 消することが期待される.

\section{コメント 5}

村山良之（山形大学）

昨年度統合新設された南阿蘇中学校で, 総合的な学 習 20 時間を使った防災教育が展開されたことが，竹 内報告で紹介された．特に忙しいとされる中学校現場 の状況と震災直後という時点で，このような充実した 防災教育が行われたことは，何より貴重だといえよ う. 中学生は, 特に高齢者の多い地域においては, 重 要な防災資源でもあり, 生徒の安全が確保される限り において，災害場面での活躍が期待されている。本実 践では，避難所運営ゲームが用いられたと紹介され た。中学生という発達段階が考慮されて自助から共助 への展開が目指された，地域と生徒の実態によく対応 した実践といえよう。

防災教育の継続については，多くの時間をかけたも のほどさまざまな困難が予想されるが，竹内氏は直接 生徒に対するのではなく, 教員への指導, 支援に徹し たことが示された，継続への重要な布石を打たれたも のと考える. 同校での取組みがモデルとなって他校や 他地域への防災教育の展開が期待されるとともに，少
し先走るが，熊本地震を経験していない世代が数年後 に中学校に入学してくることを見据えた取組みも期待 される。

同校での防災教育は，統合前すなわち震災前の久木 野中学校での実践が背景にあることも示された。防災 教育の評価は，アンケート等による実践前後の比較や 態度の変化等によって試みられることが多いが，実際 の被災経験を踏まえた検証はきわめて貴重である。旧 久木野中学校での防災教育についての熊本地震の経験 を踏まえた検証も，これを指導，支援された竹内氏に ぜひお願いしたい。

\section{文献}

熊原康博 - 後藤秀昭 - 中田 高 - 石黒 聡 - 石村大輔 . 石山達也・岡田真介・楮原京子・柏原真太郎・金田 平太郎・杉戸信彦・鈴木康弘・竹竝大士・田中 圭 - 田中知季 - 堤 浩之 - 遠田晋次 - 廣内大助 - 松 多信尚・森木ひかる・吉田春香 - 渡辺満久 2016. 2016年熊本地震の地表地震断層の分布とその特徵. 日本地球惑星科学連合 MIS34-05.

鈴木康弘・渡辺満久・中田 高 2016. 2016年熊本 地震を教訓とする活断層防災の課題と提言. 科学 86: 839-847.

中小企業庁編 2006. 『中小企業白書 2006年版』ぎょ うせい.

中田 高 - 島崎邦彦 · 鈴木康弘 - 佃 栄吉 1998. 活 断層はどこから割れ始めるのか？一活断層の分岐 形状と破壊伝播方向. 地学雑誌 107：512-528.

藤原広行 2017. 熊本地震に活きたSIPの成果—ーリ アルタイム地震被害推定・状況把握システムの開 発. 第 16 回国土セイフティネットシンポジウム講 演予稿集.

Shirahama, Y., Yoshimi, M., Awata, Y., Maruyama, T., Azuma, T., Miyashita, Y., Mori, H., Imanishi, K., Takeda, N., Ochi, Y., Otsubo, M., Asahina, D. and Miyakawa, A. 2016. Characteristics of the surface ruptures associated with the 2016 Kumamoto earthquake sequence, central Kyushu, Japan. Earth, Planets and Space 191, DOI: 10.1186/ s40623-016-0559-1 